\title{
PENGARUH METODE PEMBELAJARAN TERHADAP HASIL BELAJAR MAHASISWA
}

\author{
Sumadji \\ Dosen Pendidikan Matematika Universitas Kanjuruhan Malang
}

\begin{abstract}
Abstrak
Proses pembelajaran bagi mahasiswa tidak cukup dilakukan hanya dengan membaca, mendengar dan menulis. Pembelajaran membutuhkan banyak hal termasuk metode efektif untuk mencapai tujuan belajar secara efisien.Sekarang banyak motode pembelajaran inovatif seperti learning cycle, problem posing, dan brainstormingditerapkan oleh praktisi pendidikan dengan hasil positif.Untuk itu dilakukan penelitian untuk menjawab masalah (1) adakah pengaruh metode pembelajaran terhadap hasil belajar? (2) metode manakah yang paling efektif?Desain penelitian ini adalah Pre Test Post Test Control Design.Kelompok yang dikenai metode pembelajaran problem posing menjadi kelas kontrol.Dua kelas lainnya menjadi kelas eksperimen masing-masing dikenai metode learningcycle dan brainstorming.Dari tabel Anova angka Sig.0.042 yang kurang dari 0.05 menunjukkan bahwa hipotesis ditolak, berarti terdapat perbedaan sinifikan antara tiga hasil belajar.Perbedaan signifikan tersebut terjadi antara hasil belajar kelas LC dan kelas BS.Berdasarkan kenyataan seperti itu, disimpulkan bahwa ada pengaruh metode pembelajaran terhadap hasil belajar dan metode brainstorming lebih efektif dari dua metode lainnya.
\end{abstract}

Kata-kata kunci: Learning cycle, problem posing, brainstorming dan hasil belajar

\begin{abstract}
Absract
The learning process for students not quite done just by reading, listening and writing. Learning requires a lot of things including effective method to achieve the learning objectives efficiently. Now much innovative learning method as learning cycle, problem posing, and brainstorming applied by practitioners of education with positive results. For that conducted research to answer the question (1) is there any influence on the learning method of learning outcomes? (2) Which method is most effective?The study design was a Pre Test Post Test Control Design. Groups subjected problem posing teaching methods into the control class. Two other classes into classes each experimental subject learningcycle and brainstorming method.In this study, the effect of the method will be seen from the difference in the mean posttest scores. From the Anova table Sig. 0.042 numbers less than 0.05 indicate that the hypothesis is rejected, it means that there are differences between the three learning outcomes sinifikan. Significant differences occurred between learning outcomes $L C$ class and class $B S$. Based on such fact, it was concluded that there was an effect on learning outcomes of learning methods and methods of brainstorming more effective than the two other methods.
\end{abstract}

\section{Keywords: Learning cycle, problem posing, brainstorming and learning outcomes}

Matematika merupakan mata pelajaran penting dalam membentuk siswa untuk berfikir logis, sistematis dan konsisten.Matematika berperan sebagai acuan kecakapan dalam menyelesaikan masalah kehidupan sehari-hari.Penguasaan terhadap matematika akan memberi kemampuan kepada siapapun untuk berkompetisi di bidang ekonomi dan teknologi.

Masalah yang selalu muncul dalam dunia pendidikan adalah capaian hasil belajar kurang maksimal .Faktor penyebabnya antara lain adalah metode pembelajaran yang kurang tepat. Dengan metode seperti itu peserta didik merasa lelah dan bosan belajar.Strategi pembelajaran yang dipilih tidak membangkitkan gairah peserta didik.Pengajar tidak melakukan selingan-selingan yang menyegarkan suasana belajar.

Dewasa ini proses belajar tidak cukup hanya dengan membaca dan 
menulis. Kegiatan itu membutuhkan banyak hal termasuk adanya metode yang dapat mencapai tujuan belajar secara efektif dan efisien.Kini telah tersedia banyak sekali motode pembelajaran inovatif seperti tiga diantaranya Learning Cycle (LC), Problem Posing (PP), dan Brain Storming (BS).Ketiga metode tersebut sudah banyak diterapkan oleh para praktisi pendidikan dengan hasil yang positif. Melihat uraian di atas dan berdasarkan kenyataan, maka penulis ingin melakukan penelitian untuk menjawab: (1) adakah pengaruh metode pembelajaran terhadap hasil belajar? (2) metode manakah yang paling efektif?

Brainstorming atau curah pendapat sebanyak mungkin terhadap suatu masalah dilangsungkan dalam suatu pertemuan. Teknik ini pada dasarnya menerapkan serbuan gagasan untuk memecahkan masalah.Pada pembelajaran dengan teknik tersebut, setiap siswa dianjurkan mengajukan pendapat atau gagasan sebanyak-banyaknya untuk kemudian dicatat.

\section{Brainstorming merupakan} perpaduan dari metode tanya jawab dan diskusi.mengacu pada penggalian ide berdasarkan kreativitas berpikir manusia. Peserta diskusi bebas menyampaikan pendapat tanpa rasa takut terhadap kritik dan penilaian sebab selama tahap pengumpulan ide semua gagasan akan ditampung tanpa terkecuali. Dalam prosesnya, tidak ada perdebatan terhadap ide-ide yang muncul karena pada dasarnya metode brainstorming bertujuan mendapatkan gagasan dan ide-ide baru dari anggota kelompok dalam waktu yang relatif singkat tanpa ada kritik yang ketat.
Pendapat dari setiap siswa mungkin berbeda-beda dan memicu perbedaan pendapat antar siswa sehingga mereka dapat meningkatkan keaktifan dan komunikasi yang efektif antara siswa dengan guru maupun dengan siswa lainnya.Prinsipnya adalah (1) memperhatikan kuantitas ide sekaligus memperhatikan kualitas, (2) menetapkan tujuan khusus untuk sejumlah ide yang muncul selama proses, (3) ide awal dimulai dari individu, (4) menggunakan interaksi kelompok untuk menyaring ide dari setiap individu, (5) menyimpulkan dengan pungutan suara anggota kelompok, (6) waktu yang digunakan untuk membangkitkan ide awal tidak terlalu lama.

Walau pun telah dirancang sebaik mungkin, namun metode brainstorming memiliki kelemahan antara lain (1) beberapa pendapat tidak digunakan karena tidak sesuai atau masalah sudah terpecahkan sebelum semua pendapat dari siswa disampaikan, (2) terlalu banyak pendapat muncul akan membuat bingung dan menyesatkan karena siswa bebas untuk berpikir, (3) metode ini mengintimidasi siswa pemalu, (4) sulit mendeteksi pendapat yang sesuai dengan masalah, (5) tidak ada jaminan mendapatkan nilai baik.

Dewasa ini, problem posing merupakan kegiatan penting dalam belajar matematika. Dalam prakteknya, para siswa diberi kesempatan membuat soal-soal sendiri.Untuk meningkatkan kemampuan menyelesaikan masalah dapat dilakukan dengan membiasakan siswa mengajukan soal-soal sendiri.Membuat pertanyaanatau soal sendiri dapat 
menantang siswa lebih berpikir dan membangun pengetahuannya.

Pembuatan soal melalui dua tahap kegiatan kognitif, pertama yaitu accepting (menerima) dan kedua challenging (menantang). Tahap menerima terjadi ketika siswa membaca situasi atau informasi yang diberika guru dan menantang terjadi ketika siswa berusaha untuk mengajukan soal berdasarkan situasi atau informasi yang diberikan. Proses kognitif menerima memungkinkan siswa menempatkan informasi pada suatu jaringan struktur kognitif sehingga struktur tersebut makin kaya. Pada proses kognitifmenantangmemungkinkan jaringan stuktur yang ada bertambah semakin kuat hubungannya. Dengan demikian, pembelajaran matematika dengan pendekatanproblem posingakan menambah kemampuan, penguatan konsep dan prinsip matematika siswa.

Problem posing merupakan model yang mengharuskan siswa menyusun pertanyaan sendiri atau memecah suatu soal menjadi pertanyaan-pertanyaan yang lebih sederhana yang mengacu pada penyelesaian soal. Pengajuan soal mandiri dapat diaplikasikan dalam 3 bentuk aktivitas kognitif matematika yakni (1) pre solution posing, yaitu jika seorang siswa membuat soal dari situasi yang diadakan, (2) within solution posing, yaitu jika seorang siswa mampu merumuskan ulang pertanyaan menjadi sub-sub baru yang urutan solusinya seperti sebelumnya, (3) post solution posing, yaitu jika seorang siswa memodifikasi tujuan soal yang sudah diselesaikan untuk membuat soal yang baru sejenis.

Pembelajaran problem posinglebih dapat dikembangkan dengan memberikan masalah yang belum terpecahkan kemudian diminta siswa menyelesaikannya.Pemikiran dalam menghasilkan pertanyaan baru dari masalah matematika adalah aktivitas utama. Karena itu, kekuatan model ini adalah (1) memberi penguatan dan memperkaya konsepkonsep dasar, (2) melatih meningkatkan kemampuan belajar, (3) latihan investigasi dan pemecahan masalah.

Penerapan problem posing dalam matematika membutuhkan keterampilan: (1) menyusun strategi pengajuan soal, (2) memecahkan masalah dalam situasi matematika dan kehidupan sehari-hari, (3) menetapkan pendekatan yang tepat, (4) mengenali hubungan antara materi-materi, (5) menentukan solusi masalah baru, (6) mengajukan masalah yang kompleks sebaik mungkin, (7) menggunakan penerapan subjek yang berbeda dalam mengajukan masalah.

Siklus Belajar (Learning Cycle, $L C)$ adalah suatu model pembelajaran yang berpusat pada pebelajar (student centered). LC merupakan rangkaian tahap-tahap kegiatan yang diorganisasi sehingga pebelajar dapat menguasai kompetensi yang harus dicapai dalam pembelajaran dengan jalan berperanan aktif. $L C$ pada mulanya terdiri atas fase eksplorasi (exploration), pengenalan konsep (concept introduction), dan aplikasi konsep (concept application).

Pada tahap eksplorasi, para siswa memanfaatkan panca inderanya semaksimal mungkin berinteraksi dengan lingkungan melalui kegiatan seperti praktikum, menganalisis artikel, berdiskusi tentang fenomena alam, mengamati perilaku sosial, dan lain-lain.Dari kegiatan ini dapat timbul ketidakseimbangan dalam 
struktur mental ditandai dengan munculnya pertanyaan-pertanyaan berdaya nalar tinggi diawali dengan kata-kata seperti mengapa dan bagaimana.

Pada fase pengenalan konsep diharapkan terjadi proses menuju kesetimbangan antara konsep yang dimiliki dengan konsep yang baru dipelajari melalui menelaah pustaka dan berdiskusi. Pada tahap ini siswa mengenal istilah yang berkaitan dengan konsep baru yang sedang dipelajari. Pada fase terakhir, pebelajar menerapkanmelalui kegiatankegiatan seperti problem solving.

$L C$ merupakanmodel belajar yang berbasis konstruktivisme. Belajar adalah pengembangan aspek kognitif yang meliputi: struktur, isi, dan fungsi. Struktur intelektual adalah organisasi mental tingkat tinggi yang dimiliki individu untuk memecahkan masalah.Ini adalah perilaku khas individu dalam merespon masalah yang dihadapi. Sedangkan fungsi merupakan proses perkembangan intelektual yang mencakup adaptasi dan organisasi.

Adaptasi terdiri atas asimilasi dan akomodasi. Pada proses asimilasi individu menggunakan struktur kognitif yang ada untuk memberikan respon terhadap rangsangan yang diterimanya. Dalam asimilasi individu berinteraksi dengan data yang ada di lingkungan untuk diproses dalam struktur mentalnya. Struktur mental individu dapat berubah, sehingga terjadi akomodasi.Individu melakukan modifikasi dari struktur yang ada, hingga terjadi pengembangan struktur mental. Individu harus mengaitkan dan mengorganisasi konsep yang baru dipelajari dengan konsep lain yang telah dimiliki. Organisasi yang baik dari intelektual seseorang akan tercermin dari respon yang diberikan dalam menghadapi masalah.

Learning Cycle sebagai strategi pengajaran pertama kali dikenalkan pada akhir tahun 1960an terdiri atas 3 tahap, yaitu exploration, invention (term introduction), dan discovery (concept application).Pada tahun 1980an $L C$ dikembangkan menjadi 5 tahap, yaitu engagement, exploration, explanation, elaboration (extend), danevaluation dikenal sebagai Learning Cycle 5E.Tahapnya sebagai berikut.

1. Fase Engage(Menarik Perhatian) Fase engage merupakan fase awal di mana guru menciptakan situasi teka-teki sesuai dengan topik yang akan dipelajari. Guru dapat mengajukan pertanyaan dan jawaban dari siswa digunakan untuk mengetahui hal-hal yang telah mereka ketahui. Dalam fase ini guru dapat pula mengidentifikasi miskonsepsi siswa. Tahap engage dimaksudkan untuk menarik minat siswa mempelajari materi.

2. Fase Exploration (Eksplorasi)

Selama fase ini, siswa harus diberi kesempatan bekerja sama dengan teman-temantanpa arahan langsung dari guru. Fase ini menurut Piaget adalah fase ketidakseimbangan dimana siswa harus dibuat bingung. Di sini merupakan kesempatan siswa menguji hipotesis, berdiskusi dengan teman sekelompoknya dan menyimpulkan.

3. Fase Explain (Menjelaskan)

Pada tahap ini siswa menjelaskan tentang konsep atau ide-ide 
dengan menggunakan bahasa mereka sendiri dan memberikan kritik/ saran satu dengan yang lain. Guru menjelaskan konsep, memperbaiki bila terjadi miskonsepsi, dan memperkenalkan istilah-istilah yang ada di dalamnya.

4. Fase Expand (Perluasan)

Pada fase ini siswa mengaplikasikan konsep dan kecakapan yang telah mereka miliki terhadap situasi lain. Pada tahap ini mungkin masih ada siswa yang mengalami miskonsepsi.Kegiatan elaborasi menolong siswa untuk memperbaiki miskonsepsinya dan menyimpulkan konsep dalam konteks umum.Kegiatan ini menantang siswa-siswa menerapkan ketrampilan dan pengembangan konsep mereka pada situasi baru, untuk mendapatkan pemahaman lebih dalam.

5. Fase Evaluate (Evaluasi)

Evaluasi dilakukan selama proses pembelajaran sedang berlangsung. Guru bertugas melakukan observasi pengetahuan dan kecakapan siswa dalam mengaplikasikan konsep dan perubahan berfikir. Guru mengevaluasi pemahaman siswa terhadap konsep. Guru dapat menggunakan berbagai macam prosedur formal dan informal untuk menilai pemahaman konsep dan me-ngetahui kemajuan pembelajaran.

Belajar merupakan aktivitas pebelajar baik fisik maupun mental. Belajar dapat terjadi di mana dan kapan saja.Pengertian belajar banyak menyangkut masalah kejiwaan (psikis), dan karena itu penjelasan-penjelasan tentang pengertian belajar banyak diutarakan oleh para pakar ilmu jiwa (psikologi) belajar baik aliran konstruktivistik maupun behavioristik. Aliran konstruktivistik menekankan bahwa belajar terjadi pada proses internal, pembentukan struktur kognitif dalam diri pebelajar yang tidak kasat mata (unobservable).

Belajar ditandai dengan adanya perubahan tingkah laku sebagai hasil pengalaman yang bersifat tahan lama dan bukan sebagai hasil belajar ditandai dengan cirri-ciri: a) disengaja dan bertujuan, b) tahan lama, c) bukan karena kebetulan, dan c) bukan karena kematangan dan pertumbuhan. Belajar merupakan proses perubahan kegiatan reaksi terhadap lingkungan. Perubahan taktergolong belajar bila disebabkan oleh pertumbuhan atau obat-obatan.

Pembelajaran yang efektif adalah proses belajar mengajar yang bukan saja berfokus kepada hasil yang dicapai peserta didik, namun proses belajar efektif mampu memberikan pemahaman yang baik, kecerdasan, ketekunan, kesempatan dan mutu serta dapat memberi perubahan prilaku dan mengaplikasikannya dalam kehidupan mereka. Pembelajaran efektif juga akan melatih dan menanamkan sikap demokratis bagi siswa. Pembelajaran efektif juga dapat menciptakan suasana belajar yang menyenangkan sehingga menimbulkan kreatifitas siswa untuk belajar dengan caranya sendiri.

Pembelajaran efektif dapat diketahui dengan ciri: (1) belajar secara aktif baik mental maupun fisik, (2) metode yang bervariasi, sehingga mudah menarik perhatian siswa dan kelas menjadi hidup, (3) motivasi guru terhadap 
pembelajaran di kelas, (4) suasana demokratis di sekolah, yakni dengan menciptakan lingkungan yang saling menghormati, dapat mengerti kebutuhan siswa, tenggang rasa, memberi kesempatan kepada siswa untuk belajar mandiri, menghargai pendapat orang lain, (5) menarik hubungan pelajaran dengan kehidupan nyata, (6) interaksi belajar yang kondusif, (7) pemberian diagnosa pada kesulitan belajar, mencari faktor penyebab dan memberikan remedial.

Hasil belajar pada dasarnya merupakan perubahan perilaku sebagai capaian tindakan belajar.Senada dengan hal tersebut Winkel (2004) menyatakan bahwa perubahan yang terjadi sebagai akibat dari aktivitas disebut dengan hasil belajar.Pendapat Djamarah (2000:28) bahwa hasil belajar adalah hasil yang diperoleh berupa kesan-kesan yang memberi akibat perubahan dalam diri individu sebagai hasil dari belajar.Suryabrata (2000:45) menyatakan bahwa hasil belajar adalah sejauh mana perubahan tingkat kemampuan siswa dalam menguasai pelajaran yang telah diajarkan.Berhubungan dengan arti dari hasil belajar di sekolah secara khusus, hasil belajar adalah sejauh mana perubahan tingkat kemampuan siswa dalam menguasai pelajaran yang telah diajarkan.

Tiga ranah hasil belajar yang diutarakan oleh Bloom adalah: (1) kognitif meliputi ingatan, pemahaman, aplikasi, sintesis, dan evaluasi, (2) afektif meliputi penerimaan, jawaban atau reaksi, penilaian, organisasi, internalisasi, (3) psikomotorik meliputi gerakan reflex, ketrampilan gerakan dasar, kemampuan perceptual, keharmonisan atau ketepatan, gerakan berupa ketrampilan kompleks dan ekspresif dan interpelatif.

Empat karakteristik orang-orang yang berhasil tinggi yaitu: (1) suka mengambil resiko moderat, bukan tanpa resiko sedikit pun, (2) memerlukan umpan balik segera, 3) mementingkan keberhasilan tidak memerlukan penghargaan materi, (4) menyatu dengan tugas, berkomitmen mencapai tujuan yang telah ditetapkan.

Faktor yang mempengaruhi keberhasilan belajar dapat digolongkan ke dalam dua kelompok yaitu faktor dari dalam (intern) dan dari luar (ekstern). Faktor intern adalah factor yang terdapat dalam diri siswa yang sedang belajar. Faktir ini terpisah menjadi dua yaitu factor mental dan fisik. Faktor intern antara lain intelegensi, sikap, bakat, minat, motivasi, dan cara belajar.

Intelegensi adalah kemampuan psikofisik merealisasi rangsangan atau menyesuaikan diri terhadap lingkungan dengan cara yang tepat. Intelegensi bukanlah persoalan kualitas otak saja, melainkan juga kualitas organ-organ tubuh lainnya.Tingkat kecerdasan atau intelegensi siswa sangat menentukan tingkat belajar siswa.Semakin tinggi intelegensi seorang siswa, semakin besar peluang untuk meraih sukses.

Sikap adalah gejala afektif internal berupa kecenderungan merespon dengan cara yang relatif tetap. Sikap positif siswa terutama kepada guru dan pelajaran merupakan awal yang baik bagi proses belajar. Sebaliknya, sikap buruk terhadap guru dan pelajaran dapat menimbulkan kesulitan belajar.

Bakat adalah kemampuan positif yang dimiliki seseorang untuk mencapai 
keberhasilan pada masa yang akan datang. Dengan demikian setiap siswa pasti memiliki bakat atau berpotensi untuk mencapai prestasi sampai ke tingkat tertentu sesuai dengan kapasitas masingmasing.Bakat mirip dengan intelegensi, yaitu dapat memberi pengaruh terhadap prestasi belajar bidang studi tertentu.

Minat adalah kecenderungan atau keinginan terhadap sesuatu. Misalnya seorang siswa yang menaruh minat besar terhadap matematika lebih banyak memusatkan perhatiannya terhadap matematika daripada siswa lain. Karena pemusatan perhatian yang intensif terhadap suatu pelajaran, maka intensitas belajarnya meningkat dan akhirnya mencapai prestasi lebih baik.

Motivasi adalah keadaan yang mendorong untuk berbuat sesuatu secara terarah.Motivasi merupakan semangat atau gairah yang berada dalam jiwa seseorang.Dorongan berguna dan sangat diperlukan untuk mencapai prestasi belajar yang baik.

Faktor eksternal adalah faktor yang berada di luar diri individu. Contoh faktor eksternal adalah: (1) lingkungan sosial di sekolah seperti guru, pegawai, teman-teman akan mempengaruhi keberhasilan belajar sswa, (2) lingkungan sosial di masyarakat seperti tetangga, kawan sepermainan, (3) lingkungan social keluarga seperti orangtua, saudara, kerabat dekat, dan lain-lain. Faktor-faktor tersebut sangat berpengaruh terhadap hasil belajar siswa. Lingkungan non sosial seperti gedung sekolah, rumah tinggal siswa, fasilitas belajar dan cuaca juga akan mempengaruhi keberhasilan belajar.

\section{Metode Penelitian}

Penelitian ini merupakan penelitian eksperimen semu (Quasi Experimental). Jenis ini memiliki kesamaan dengan penelitian eksperimen murni, hanya berbeda dalam pengontrolan variabel.Dalam penelitian eksperimen semu sering tidak dapat melakukan randomisasi. Desain penelitian ini termasuk Pre Test Post Test Control Design, di mana kelompok yang dikenai metode pembelajaran problem posing menjadi kelas control. Kelas-kelas lainnya merupakan kelas eksperimen.

Untuk penelitian ini penulis menyusun enam macam tes.Seluruh tes diujicobakan terhadap kelas yang tidak terpilih menjadi subyek penelitian.Setelah didapatkan butir-butir yang valid dan reliabel, dengan daya pembeda dan tingkat kesukaran yang cukup, maka seluruh tes tersebut dapat digunakan.

Validitas instrumen ditentukan dengan membandingkan indeks korelasi Product Moment Pearson $r$ yang diperoleh pada level signifikansi $5 \%$ dengan nilai kritisnya.Jika $\mathrm{r}_{\text {hit }} \geq \mathrm{r}_{\text {tabel }}$ pada taraf nyata $5 \%$, maka item dinyatakan valid. Dalam hal lain item-item dinyatakan tidak valid.

Untuk reliabilitas instrumen ditentukan mengghunakan bantuan program SPSS dengan mencari harga Cronbach's Alpha yang kemudian dibandingkan dengan harga baku 0,6. Jika harga Alpha $\geq 0,6$ maka berarti instrumen reliabel. Dalam hal lain, instrumen tidak reliabel.

Daya pembeda suatu instrumen adalah kemampuan instrumen tersebut membedakan siswa berkemampuan tinggi dengan siswa berkemampuan rendah. Besarnya daya pembeda disebut indeks diskriminasi disingkat D. Interpretasi D 
dengan rentangan 0,20 sampai 0,40 adalah 'cukup', di bawahnya adalah jelek dan di atasnya adalah baik. Tingkat kesukaran 'cukup' terletak pada kisaran 0,30 sampai 0,70, di bawahnya adalah 'mudah' dan di atasnya adalah 'sukar'.

Hipotesis diuji menggunakan analysis of variance satu jalur.Ketiga kelompok data hasil belajar dari tiga sampel independen baik hasil tes awal mau pun tes akhir harus berdistribusi normaldengan varians homogen(equal). Untuk hasil tes awal akan ditunjukkan tidak terdapat perbedaan rerata yang signifikan. Namun untuk rerata hasil tes akhir akan dibuktikan berbeda secara signifikan atau tidak.

Uji kenormalan distribusi data dilakukan dengan uji KolmogorovSmirnov.Jika angka asymp.Sig. (2-tailed) lebih dari 0.05 maka data hasil belajar tersebut berdistribusi normal.Angka 0.05 adalah standar umum yang sering digunakan dalam penelitian.

Untuk menguji homogenitas variansnya ditempuh menggunakan Levene test. Jika angka sig. nilainya lebih dari 0.05 maka varians ketiga hasil belajar tersebut sama. Dalam hal lainnya, varians tidak homogen.

Kriteria penolakan $\mathrm{H}_{\mathrm{o}}$ adalah jika dalam Anova didapatkan angka sig. kurang dari 0.05 , maka $\mathrm{H}_{\mathrm{o}}$ ditolak.Hal itu berarti, ada perbedaan signifikan antara ketiga hasil belajar.Hasil di atas ditegaskan lagi oleh uji Post Hoc Duncan.Jika hasil belajar tiap metode terletak pada kolom subset berbeda, maka berarti ketiga hasil belajar memiliki perbedaan signifikan.

Jika ternyata ada perbedaan signifikan antara tiga hasil belajar, maka akan dilanjutkan uji Post Hoc untuk melihat hasil-hasil belajar mana yang berbeda. Jika berdasarkan uji homogenitas varians ketiganyasama, maka akan dilakukan uji Post Hoc Bonferroni, jika tidak homogen, maka digunakan uji Games-Howell. Jika dari tabel Benferroni dapat dilihat bahwa seluruh angka sig. kurang dari 0.05, maka hal itu berarti perbedaan meannya signifikan.Demikian juga jika pada tabel Duncan nilai harmonic meannya tiap kelas berada dalam kolom subset yang berbeda, maka berarti perbedaan meannya signifikan.

\section{Hasil Penelitian dan Pembahasan}

Perangkat Pretes diuji cobakan terhadap 39 mahasiswa dari kelas yang tidak dikenai tindakan. Perangkat Postes diujicobakan terhadap kelas yang sama namun dengan jumlah mahasiswa 40 orang. Hasil analisis validitas menunjukkan keduanya valid sehingga dapat dipergunakan. Dari analisis reliabilitas didapat koefisien alpha Cronbach Pretes dan Postes berturut-turut adalah 0.663 dan 0.719 , keduanya berada di atas 0,600 . Karena itu, kedua perangkat soal tersebut dinyatakan reliabel.Dari analisis butir soal dapat dinyatakan bahwa pretes dan postes memiliki daya pembeda sedang dan tingkat kesukaran cukup.

Dari hasil uji KolmogorovSmirnov, tiga kelompok data Pretes dinyatakan normal dengan angka Asymp.Sig. semuanya di atas 0.05Demikian pula untuk data Postes dinyatakan normal dengan angka Asymp.Sig. semua di atas alpha 0.05.

Untuk melihat homoginitas varians data pretes dan postes digunakan uji Levene. Dengan uji tersebut didapatkan 
angka Sig. baik untuk Pretes mau pun Postes berturut-turut adalah 0.402 dan 0.232 keduanya lebih dari 0,05 . Dengan demikian dinyatakan kedua kelompok data tersebut memiliki varians homogen.

Penelitian ini dimulai dari rerata pretes tiga kelas yang tidak berbeda secara signifikan.Selanjutnya harus ditunjukkan ketiga rerata berbeda tetapi tidak signifikan dengan hipotesis sebagai berikut.Dari angka Sig.0.987 lebih dari 0.05 disimpulkan bahwa tidak terdapat perbedaan signifikan antara tiga prestasi pada Pretes. Di tabel Multiple Comparisons semua angka Sig. lebih dari 0.05 yang berarti bahwa ketiga data Pretes tidak berbeda secara signifikan.

Dalam penelitian ini, pengaruh metode akan dilihat dari peningkatan kemampuan mahasiswa yaitu selisih skor postes dengan skor pretes. Karena skor pretes tidak berbeda secara signifikan antara ketiga kelas, maka pengaruh metode pembelajaran dilihat dari beda rerata skor postes. Hipotesisnya adalah: $\mu_{1}=\mu_{2}=\mu_{3}$

Dari tabel Anova angka Sig. 0.042 kurang dari 0,05 menunjukkan bahwa hipotesis ditolak, berarti terdapat perbedaan sinifikan antara tiga hasil belajar. Juga pada tabel Multiple Comparisons beberapa angka Sig. kurang dari 0.05 , artinya bahwa beberapa hasil belajar berbeda secara signifikan.Perbedaan yang signifikan tersebut terjadi antara hasil belajar kelas $L C$ dan kelas $B S$.

Rerata hasil belajar berturut-turut untuk kelas $L C, P P$ dan $B S$ adalah 63.06, 62.60 dan 69.55. Berdasar analisis, reratarerata tersebut berbeda secara signifykan.Dari hal tersebut dikatakan terdapat perbedaan signifikan hasil belajar antara tiga kelas. Dengan kata lain, metode belajar yang diterapkan memberikan efek berbeda. Namun berdasarkan analisis selanjutnya, hanya hasil belajar kelas $L C$ yang berbeda secara signifikan dengan hasil belajar kelas $B S$.

Selama proses belajar, kelas $L C$ mengalami hambatan yang cukup berarti ketika memasuki tahap Explain (menjelaskan). Umumnya mahasiswa tidak terbiasa berbicara seorang diri di tengah-tengah kelas.Pada saat ini mereka benar-benar tidak memiliki rasa percaya diri. Sementara itu pada tahap ini mahasiswa dituntut dapat menjelaskan konsep, idea, gagasan, kritik atau bantahan dengan bahasa mereka sendiri.Kondisi seperti ini mengintimidasi terutama mahasiswa pemalu, daya nalar mereka terganggu sehingga pemahamannya menurun.

Hambatan serupa terjadi pada kelas PP di mana setiap mahasiswa harus mengajukan soal yang mereka buat sendiri.Pada bagian ini terdapat dua kesulitan yaitu kesulitan tentang konsep matematika dan kesulitan menyusun kalimat disertai kurangnya rasa percaya diri mereka sebagaimana yang dialami siswa di sekolah menengah. Berhubungan dengan hal ini Silver dan Cai (1996) menyatakan bahwa kesukaran yang dialami siswa ketika merumuskan pertanyaan berkaitan dengan struktur bahasa (sintaksis) dan struktur matematika (semantik).

Sementara pada proses belajar di kelas BS tidak terlihat adanya hambatan mengingat dalam penerapan metode brainstorming siapa pun tidak diperkenankan menanggapi saran yang dibuat oleh peserta. Kumpulan saran-saran dibahas bersama untuk dipilih yang 
relevan dan bermanfaat untuk memecahkan masalah.Karena itu, mereka tidak merasa tertekan selama mengikuti proses belajar.

Penafsiran metode belajar yang efektif dilihat dari tingginya hasil belajar yang dicapai oleh suatu kelas pada postes dan adanya signifikansi antara dua kelas yang dibandingkan. Dari uraian sebelumnya dapat dikatakan bahwa metode belajar brainstorming lebih efektif dibanding dengan metode learning cycle.Namun metode brainstorming tidak lebih efektif dibandingkan dengan metode problem posing. Demikian pula tidak terdapat perbedaan keefektifan antara metode learningcycle dengan metode problemposing. Disimpulkan bahwa metode brainstorming lebih efektif dari metodemetode lainnya.

\section{Pustaka Rujukan}

Djamarah, S. Bahri. 2000. Guru dan Anak Didik dalam Interaksi Edukatif. Jakarta: P.T. Rineka Cipta.

Sardiman, A. M. 1998. Interaksi dan Motivasi Belajar Mengajar, Pedoman bagi Guru dan Galon Guru. Jakarta: P.T. Raja Grafindo Persada.

Silver, E.A. and Cai, J. 1996. An Analysis of Arithmetics Problem Posing by Middle School Student. Journal for Research in Matehematics Education, 27:293-309.

Slameto. 2003. Belajar dan Faktor-faktor yang Mempengaruhinya. Jakarta: Penerbit Rineka Cipta.
Suryabrata, Sumadi. 2000. Psikologi Pendidikan. Jakarta: P.T. Rajawali.

Suryanto. 1998. Problem Posing dalam Pembelajaran Matematika. Makalah disampaikan dalam Seminar Nasional. Malang: PPS IKIP Malang.

Winkel. 2004. Psikologi Pengajaran. Jakarta: P.T. Gramedia. 